\title{
Assessment of genetic diversity for quantitative traits in sunflower germplasm
}

Naila Gandahi ${ }^{1}$, Aftab Ahmed Mahar ${ }^{2}$, Abdul Wahid Baloch ${ }^{1}$, Sarfraz Ahmed Ansari ${ }^{3}$, Tauqeer Ahmad Yasir ${ }^{4}$, Munaiza Baloch ${ }^{1 *}$, Liaquat Ali Bhutto $^{5}$, Asad Mari ${ }^{6}$ and Tanweer Fatah Abro ${ }^{1}$

1. Department of Plant Breeding \& Genetics, Sindh Agriculture University, Tandojam-Pakistan

2. Wheat Section, Agriculture Research Institute, Tandojam-Pakistan

3. Southern Wheat Research Station, Tandojam-Pakistan

4. College of Agriculture, Bahauddin Zakaria University, Bahadur Sub-Campus Layyah-Pakistan

5. Oilseeds Section, Agriculture Research Institute, Tandojam-Pakistan

6. Institute of Food Sciences \& Technology, Sindh Agriculture University, Tandojam -Pakistan

*Corresponding author's email: balochbreeders@yahoo.com

Citation

Naila Gandahi, Aftab Ahmed Mahar, Abdul Wahid Baloch, Sarfraz Ahmed Ansari, Tauqeer Ahmad Yasir, Munaiza Baloch, Liaquat Ali Bhutto, Asad Mari and Tanweer Fatah Abro. Assessment of genetic diversity for quantitative traits in sunflower germplasm. Pure and Applied Biology. Vol. 6, Issue 1, pp261-266.

http://dx.doi.org/10.19045/bspab.2017.60022

Received: 17/09/2016

Revised: 06/02/2017

Accepted: $12 / 02 / 2017$

Online First: 18/02/2017

\section{Abstract}

Evaluating genetic diversity in germplasm resources is a prerequisite for any effective breeding program. In this context, an investigation was carried out for analyzing genetic diversity in a set of 18 sunflower lines, which were grown at Oilseeds Section, Agriculture Research Institute, Tandojam, Sindh, Pakistan. Results demonstrated that mean squares were highly significantly different $(P<0.01)$ for days to flowering, days to maturity, plant height, head diameter, seeds head $^{-1}$, seed index and grain yield plant ${ }^{-1}$. It represents that studied sunflower germplasm tend to have useful genetic resources for further breeding programs. In respect to genetic distance, a number of pairs were identified, which possess wide as well as narrow genetic distance; hence these pairs may be utilized for heterosis and backcross breeding purpose, respectively. Principal component analysis depicted that first three components showed a very high percentage of genetic variance $(91.60 \%)$, indicating a great amount of genetic diversity in studied germplasm. Considering cluster analysis, diverse parents have also been identified through different clusters, signifying their importance for upcoming hybridization programs in sunflower.

Keywords: Genetic diversity; Sunflower; Cluster analysis; Quantitative traits

\section{Introduction}

Sunflower is considered as a major source of edible oil and a nice fit in the cropping system of Pakistan. Sunflower has potential to meet the country's domestic needs [1]. Sunflower has a worth in bridging the gap between demand and supply of edible oil to a substantial level in the coming years [2]. Genetic diversity plays a vital role in crop breeding, since obtained hybrids from the germplasm of diverse origin usually exhibit a great amount of heterosis than those 
between closely related lines [3]. In turn to get improvement in the crop production, plant breeders are being associated to evaluate the genotypes contemplating essential aspects in the production process [4]. Improvement in sunflower, highlights the earnestness of breeding a heterotic hybrid that is attained by heterotic vigour offered in the genetically assorted parental genotypes. Hybridization that involves genetically divergent parents will result in improved vigour in the resultant hybrid. In this regard, several studies have been conducted in order to assess the genetic divergence in sunflower crop by using morphoagronomic characters $[2,3,5,6,7]$. In this context, an attempt was made to explore genetic diversity in a set of sunflower genotypes.

\section{Materials and methods}

A set of sunflower germplasm, including eighteen new sunflower lines (Line-1, Line2, Line-3, Line-4, Line-5, Line-6, Line-7, Line-8, Line-9, Line-10, Line-11, Line-12, Line-13, Line-14, Line-15, Line-16, Line-17 and Line-18) were sown in the experimental field of Oilseeds Section, A.R.I., Tandojam during the spring growing season, 2015. The research was conducted in a randomized complete block design with four repeats. The distance of 25 and $60 \mathrm{~cm}$ was maintained between plant to plant and row to row, respectively. At maturity, ten plants per genotype per replication were selected and tagged as index plants for recording data on days to $90 \%$ flowering, days to maturity, plant height $(\mathrm{cm})$, head diameter $(\mathrm{cm})$, seeds head $^{-1}$, seed index (1000-achene weight, g) and seed yield plant ${ }^{-1}$ (g). Analysis of variance and principal component analysis (PCA) was carried out through computer package Statistix Ver. 8.1, while genetic distance and cluster analysis was done through SPSS (Ver. 21) computer package.

\section{Results and discussion}

Analysis of variances

The mean squares of different quantitative traits (Table 1) exhibited that genotypes were significantly different $(\mathrm{P} \leq 0.01)$ for days to $90 \%$ flowering, days to maturity, plant height, head diameter, seeds head ${ }^{-1}$, seed index and seed yield plant ${ }^{-1}$. It signifies the presence of considerably high genetic diversity among the tested sunflower lines for studied traits. Similar results were also obtained by Khan et al. [8] and Memon et al. [9].

Table 1. Mean squares from analysis of variance for various traits in sunflower genotypes

\begin{tabular}{|l|l|l|l|l|l|l|l|l|}
\hline $\begin{array}{l}\text { Source of } \\
\text { variation }\end{array}$ & D.F & $\begin{array}{l}\text { Days to } \\
\text { flowering }\end{array}$ & $\begin{array}{l}\text { Days to } \\
\text { maturity }\end{array}$ & $\begin{array}{l}\text { Plant } \\
\text { height }\end{array}$ & $\begin{array}{l}\text { Head } \\
\text { diameter }\end{array}$ & $\begin{array}{l}\text { Seeds } \\
\text { head }\end{array}$ & $\begin{array}{l}\text { Seed } \\
\text { index }\end{array}$ & $\begin{array}{l}\text { Seed } \\
\text { yield } \\
\text { plant }^{-1}\end{array}$ \\
\hline Replications & 3 & 20.30 & 12.53 & 100.70 & 43.75 & 779.1 & 14.66 & 20.25 \\
\hline Genotypes & 17 & $34.46^{* *}$ & $33.86^{* *}$ & $1239.71^{* *}$ & $7.83^{* *}$ & $61147.5^{* *}$ & $125.22^{* *}$ & $201.40^{* *}$ \\
\hline Error & 51 & 3.00 & 3.37 & 43.31 & 2.14 & 410.1 & 7.93 & 11.02 \\
\hline
\end{tabular}

$* *=$ indicates significant level at 0.01 of probability level

\section{Genetic distance}

Considering the genetic distance, it ranged between 11.06 and 605.7. Out of 154 pair of comparisons from genetic distance (Table 2), quite a high numbers of pairs revealed very wide genetic distance, such as Line-3 and Line-17 (605.7), followed by Line-1 and Line-17 (489.8), Line-11 and Line-17
(427.0), Line-3 and Line-7 (411.4), Line-15 and Line-17 (375.5), Line-13 and Line-17 (367.3), Line-2 and Line-17 (367.0), Line4 and Line-17 (357.8), Line-3 and Line-10 (354.0). Of the special note, these pairs can better be utilized for heterosis breeding program in sunflower breeding; since these pairs contain variety of genes for various 
traits. However, the narrow genetic distance was found between Line-9 and Line-13 (11.6), followed Line-13 and Line-15 (15.0), Line-2 and Line-15 (16.4), Line-10 and Line-15 (17.8), Line-8 and Line-14 (18.7), Line-2 and Line-4 (18.8) and Line-2 and Line-13 (21.8). Hence, these pairs of genotypes could be proved reliable breeding materials for backcross breeding. In agreement to our findings, Punitha et al. [2] and Shamshad et al. [6] also reported a wide divergence between sunflower lines.

\section{Principal component analysis}

PCA analysis is a very useful statistical technique for identification of genetic diversity, tracing the pathway to evolution of crops, parental selection, centre of origin and diversity, and to study the interaction between environments [10]. PCA analysis revealed that first three components explained $91.60 \%$ of the total variations, which is consider a very huge genetic variance for the studied traits among the sunflower genotypes (Table 3). The first, second and third components accounted $46.50 \%, 32.90 \%$ and $12.20 \%$ of the variation found in the Eigen vector analysis (Table 3). In the first principal component, seed yield plant ${ }^{-1}(0.48)$, plant height $(0.45)$ and head diameter (0.44) were the most important contributing characters. Similarly, days to heading $(0.51)$, days to maturity (0.50) and seed index (0.49) were the important genetic parameters in second principal component. It is clearly noted that germplasm tend to possess a very wide genetic distance for quantitative traits, yet these sunflower lines may be preferred in breeding programs to improve existing cultivars. The significance of PCA analysis also suggested by other sunflower researchers in conventional breeding for genetic divergence, germplasm assortment and cultivar development $[7,11,12]$.

\section{Cluster analysis}

Cluster analysis is one of the most important multivariate analyses, which assist grouping of genotypes based on genetic diversity that is existed for various traits among the genotypes [13]. The un-weighted pair group method using arithmetic average (UPGMA) classified the 18 sunflower lines into 4 small clusters (Figure 1). This indicates the presence of wide genetic diversity among the tested genotypes. The first cluster consisted of six sunflower lines, including Line-9, Line-13, Line-2, Line-15, Line-18 and Line-4; while, second cluster comprised of three germplasm of sunflower, such as Line-1, Line-11 and Line-3. The third cluster retained maximum (7 lines) sunflower lines, namely Line-10, Line-16, Line-12, Line-8, Line-14, Line-5 and Line6; whereas, last and fourth cluster contained only one sunflower line (Line-17). It reveals that there is good enough genetic diversity available in the tested genotypes, hence it is proposed that different sunflower lines from different clusters may be hybridized in order to get maximum heterosis for various quantitative traits. In agreement to our results, various researchers $[2,3,6]$ also reported a wide genetic diversity in sunflower germplasm through cluster analysis. 
Table 2. Genetic distance among various sunflower genotypes

\begin{tabular}{|c|c|c|c|c|c|c|c|c|c|c|c|c|c|c|c|c|c|}
\hline Genotypes & 1 & 2 & 3 & 4 & 5 & 6 & 7 & 8 & 9 & 10 & 11 & 12 & 13 & 14 & 15 & 16 & 17 \\
\hline Line-1 & .000 & & & & & & & & & & & & & & & & \\
\hline Line-2 & 123.3 & .000 & & & & & & & & & & & & & & & \\
\hline Line-3 & 116.6 & 239.4 & .000 & & & & & & & & & & & & & & \\
\hline Line-4 & 132.3 & 18.8 & 248.4 & .000 & & & & & & & & & & & & & \\
\hline Line-5 & \begin{tabular}{|l|}
175.7 \\
\end{tabular} & 53.9 & 291.6 & 44.6 & .000 & & & & & & & & & & & & \\
\hline Line-6 & \begin{tabular}{|l|}
180.7 \\
\end{tabular} & 57.9 & 296.7 & 55.0 & 24.4 & .000 & & & & & & & & & & & \\
\hline Line-7 & \begin{tabular}{|l|}
295.7 \\
\end{tabular} & 172.7 & 411.4 & 167.1 & 124.1 & 115.3 & .000 & & & & & & & & & & \\
\hline Line-8 & 211.2 & 90.5 & 327.2 & 78.9 & 37.6 & 45.5 & 96.3 & .000 & & & & & & & & & \\
\hline Line-9 & 136.4 & 30.2 & 249.5 & 43.5 & 56.3 & 54.9 & 164.3 & 92.5 & .000 & & & & & & & & \\
\hline Line-10 & 238.4 & 115.4 & 354.0 & 110.6 & 68.1 & 58.0 & 58.5 & 48.5 & 106.9 & .000 & & & & & & & \\
\hline Line-11 & 67.0 & 61.2 & 180.7 & 74.6 & 114.5 & 116.7 & 231.1 & 151.2 & 70.2 & 173.6 & .000 & & & & & & \\
\hline Line-12 & \begin{tabular}{|l|}
212.7 \\
\end{tabular} & 91.0 & 327.2 & 88.3 & 47.7 & 39.2 & 87.6 & 46.2 & 78.4 & 32.0 & \begin{tabular}{|l|}
147.3 \\
\end{tabular} & .000 & & & & & \\
\hline Line-13 & 126.8 & 21.8 & 240.8 & 36.8 & 58.6 & 60.1 & 171.9 & 96.0 & 11.6 & 114.4 & \begin{tabular}{|l|}
61.4 \\
\end{tabular} & 86.5 & .000 & & & & \\
\hline Line-14 & 208.3 & 85.6 & 324.2 & 77.4 & 33.1 & 34.7 & 91.9 & 18.7 & 82.2 & 37.8 & 145.8 & 27.9 & 87.4 & .000 & & & \\
\hline Line-15 & 117.2 & 16.4 & 232.1 & 34.5 & 64.9 & 65.5 & 179.8 & 101.8 & 23.4 & 122.0 & 51.7 & 96.0 & 15.0 & 94.8 & .000 & & \\
\hline Line-16 & 220.9 & 97.8 & 336.7 & 93.0 & 51.3 & 40.3 & 75.6 & 37.8 & 90.8 & 17.8 & 156.4 & 22.5 & 97.7 & 24.3 & 104.8 & .000 & \\
\hline Line-17 & \begin{tabular}{|l|}
489.8 \\
\end{tabular} & 367.0 & 605.7 & 357.8 & 314.2 & 311.2 & 200.5 & 279.3 & 360.1 & 254.8 & 427.0 & 282.0 & 367.3 & 281.7 & 375.5 & 271.5 & .000 \\
\hline Line-18 & 137.6 & 18.8 & 253.7 & 26.7 & 45.5 & 44.3 & 158.3 & 81.1 & 30.4 & 101.7 & 74.6 & 78.6 & 27.3 & 74.4 & 27.4 & 84.2 & 354.4 \\
\hline
\end{tabular}


Table 3. PCA analysis for studied characters in 18 sunflower lines

\begin{tabular}{|l|c|c|c|}
\hline Traits & PC1 & PC2 & PC3 \\
\hline Days to heading & -0.30 & 0.51 & 0.24 \\
\hline Days to maturity & -0.32 & 0.50 & 0.21 \\
\hline Head diameter & 0.44 & 0.15 & -0.51 \\
\hline Plant height & 0.45 & -0.02 & 0.34 \\
\hline Seed yield plant ${ }^{-1}$ & 0.48 & 0.01 & -0.43 \\
\hline Seed index & -0.17 & 0.49 & 0.55 \\
\hline Eigen values & 3.25 & 2.30 & 0.85 \\
\hline Percentage of variance & 46.50 & 32.90 & 12.20 \\
\hline Cumulative percentage of variance & 46.50 & 79.40 & 91.60 \\
\hline
\end{tabular}

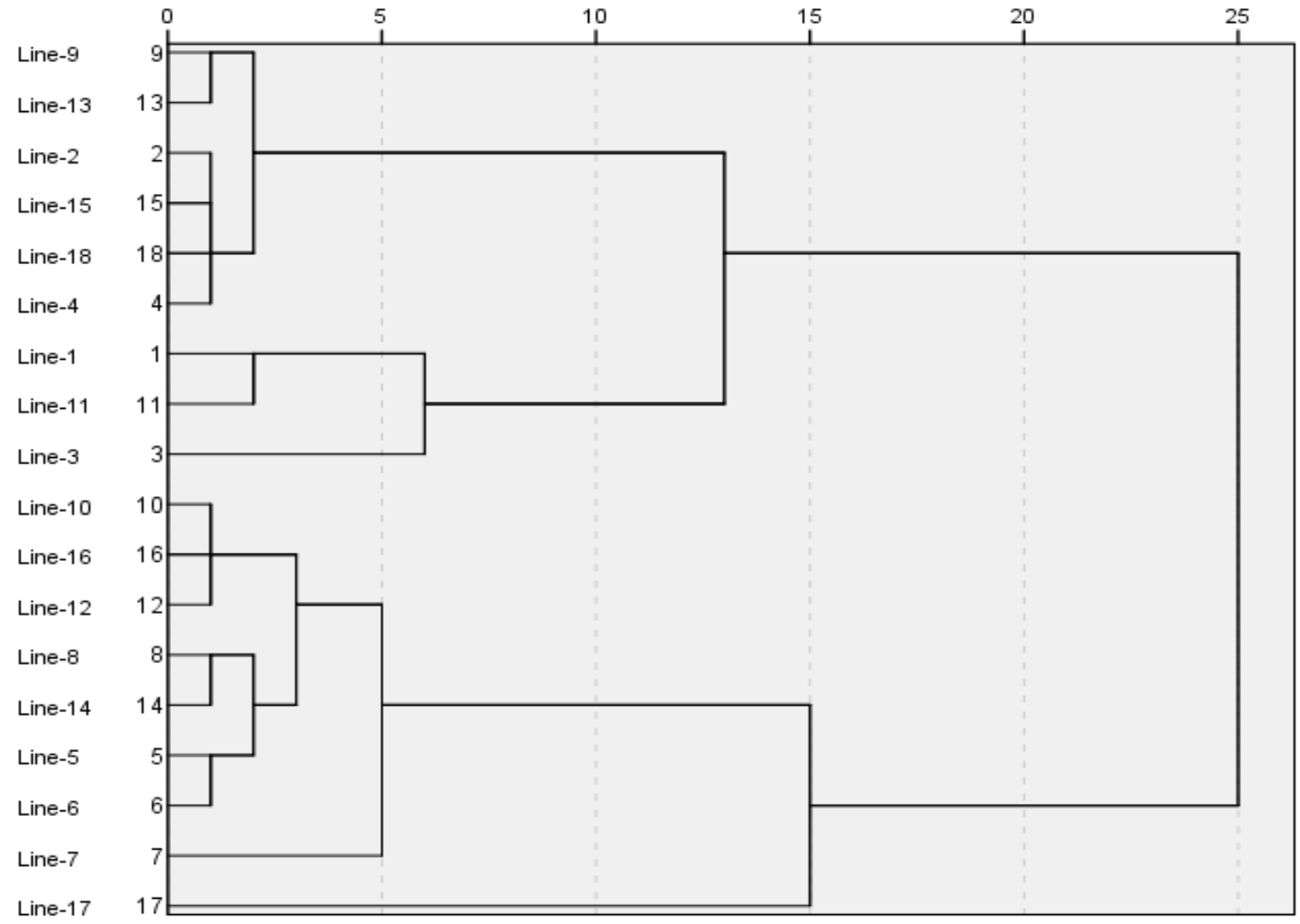

Figure 1. Tree diagram based on agronomical traits of 18 sunflower lines

\section{Conclusions}

It is concluded that highly significant differences were observed among sunflower genotypes evaluated for all the seven studied traits. The results of the current study show the presence of genetic diversity among selected sunflower genotypes. Parents from divergent clusters may be used for hybridization in order to isolate useful recombinants in the segregating generations.

\section{Author's contributions}

Conceived and designed the experiments: $\mathrm{N}$ Gandahi, AW Baloch \& TF Abro. Performed the experiments: N Gandahi. Analyzed the data: AA Mahar, TA Yasir \& A Marri. Contributed reagents/ materials/ analysis tools: AW Baloch \& LA Bhutto. 
Wrote the paper: N Gandahi, AW Baloch, SA Ansari, M Baloch

\section{References}

1. Habib H, Mehdi SY, Anjum MA, Mohyuddin ME \& Zafar M (2007). Correlation and path analysis for seed yield in sunflower (Helianthus annuus L.) under charcoal rot (Macrophomina phaseolina) stress conditions. Int J Agri Bio 9(2): 362-264.

2. Punitha B, Vindhiyavarman $\mathrm{P} \quad \&$ Manivannan N (2010). Genetic divergence study in sunflower (Helianthus annuus L.). Elect J Plant Breed 1(4): 426-430.

3. Sujatha K \& Nadaf HL (2013). Correlation for yield and yield related traits in mutant and segregating genotypes in sunflower (Helianthus annus. L). Mol Plant Breed 32: 265-266.

4. Messetti AVL \& Padovani CR (2004). O uso da dispersão gráfica por variáveis canônicas com ênfase em melhoramento genetic, Uberlândia 2: 373- 376.

5. Arshad M, Ilyas MK \& Khan MA (2007). Genetic divergence and path coefficient analysis for seed yield traits in sunflower (Helianthus annuus L.) hybrids. Pak J Bot 39: 2009-2015.

6. Shamshad M, Dhillon SK, Tyagi V \& Akhtar J (2014). Assessment of genetic diversity in sunflower (Helianthus annuus L.) germplasm. Int J Agri Food Sci Tech 5(4): 267-272.

7. Masvodza DR, Gasura E, Zifodya N, Sibanda P \& Chisikaurayi B (2015). Genetic diversity analysis of local and foreign sunflower germplasm (Helianthus annuus) for the national breeding program: Zimbabwe. J Cereals Oilseeds 6(1): 1-7.

8. Khan H, Rehman HU, Bakht J, Khan AK, Hussain I, Khan A \& Ali S (2013). Genotype $\times$ environment interaction and heritability estimates for some agronomic characters in sunflower. The J Ani Plant Sci 23(4): 1177-1184.

9. Memon S, Baloch MJ, Baloch GM \& Keerio MI (2014). Heritability and correlation studies for phenological, seed yield and oil traits in sunflower (Helianthus annuus L). Pak J Agri Agril Engg Vet Sci 30 (2): 159-171.

10. Khodadadi M, Fotokian MH \& Miransari M (2011). Genetic diversity of wheat (Triticum aestivum L.) genotypes based on cluster and principal component analyses for breeding strategies. Aus J Crop Sci 5(1): 17-24.

11. Ghaffari M (2004). Use of principal component analysis method for selection of superior three way crosses hybrids in sunflower. Seed and Plant 19(4): 513-527.

12. Ghaffoor A \& Arshad M (2008). Multivariate analysis for quantitative traits to determine genetic diversity of black gram (Vigna mungo L. Hepper) germplasm. Pak J Bot 40(6): 23072313.

13. Baloch AW, Baloch M, Jatoi SH, Baloch MJ, Baloch GM, Mugheri MA, Depar MS, Mallani IA, Baloch AM, Gandhai N, Baloch IA \& Ali M (2015). Genetic diversity analysis in genetically modified cotton (Gossypium hirsutum L.) genotypes. Sindh Univ Res J 47(3): 527-530. 